\title{
Qualitative content analysis
}

\author{
Rika Preiser, ${ }^{1}$ María Mancilla García, ${ }^{2}$ Lloyd Hill ${ }^{3}$ and Louis Klein ${ }^{4}$ \\ ${ }^{1}$ CENTRE FOR SUSTAINABILITY TRANSITIONS, STELLENBOSCH UNIVERSITY, STELLENBOSCH, SOUTH AFRICA \\ ${ }^{2}$ STOCKHOLM RESILIENCE CENTRE, STOCKHOLM UNIVERSITY, STOCKHOLM, SWEDEN \\ ${ }^{3}$ DEPARTMENT OF SOCIOLOGY AND SOCIAL ANTHROPOLOGY, STELLENBOSCH UNIVERSITY, \\ STELLENBOSCH, SOUTH AFRICA \\ ${ }^{4}$ EUROPEAN SCHOOL OF GOVERNANCE, BERLIN, GERMANY; INTERNATIONAL \\ FEDERATION FOR SYSTEMS RESEARCH, AUSTRIA
}

\section{Key methods discussed in this chapter}

Discourse analysis, critical discourse analysis, thematic analysis, narrative analysis, critical narrative analysis, interpretative phenomenological analysis

\section{Connections to other chapters}

Methods used for qualitative analysis treat language as a resource that has agency to shape societal practices and institutions. By using certain words or phrases, language and discourse convey certain power relations and influence worldviews, societal forms and actions. By analysing how language and other forms of non-textual representation (such as descriptions, accounts, opinions, feelings) are being used in various contexts, this chapter links well to Chapter 5 (Systems scoping), Chapter 7 (Interviews and surveys), Chapter 8 (Participatory data collection), Chapter 9 (Facilitated dialogues), Chapter 10 (Futures analysis), Chapter 11 (Scenario development) and Chapter 20 (Comparative case study analysis). The set of methods proposed in this chapter are all well equipped to discover trends in how content is developed and knowledge generated.

\section{Introduction}

Qualitative methods of content analysis seek to find and examine patterns of sense-making and meaning creation in the communicative characteristics of language, by focusing on the content and underlying themes and meaning that emerge in a text (in either written or spoken form). The word 'text' here points to a wide range of phenomena such as descriptions, accounts, opinions and feelings that are conveyed in a variety of representations, not only as letters on a white page or screen. Qualitative data can be represented in words, pictures and even sounds.

Nowadays the word 'text' can be applied to landscapes, heritage sites, technologies, urban spaces or institutional practices - all phenomena that can be 'read' in a certain way. Drawing on the implications of the 'linguistic turn' that was introduced in the humanities by French linguist Ferdinand de Saussure (1974), researchers from other disciplines have developed 


\begin{tabular}{|c|c|}
\hline \multicolumn{2}{|c|}{ SUMMARY TABLE: QUALITATIVE CONTENT ANALYSIS } \\
\hline DISCIPLINARY BACKGROUND & KNOWLEDGE TYPE \\
\hline $\begin{array}{l}\text { The methods in this chapter are derived } \\
\text { from or have most commonly been used in: } \\
\text { Semiotics, Psycholinguistics, } \\
\text { Psychology, Sociolinguistics, } \\
\text { Pragmatism, Sociology, Management } \\
\text { and Organisational Studies, Media and } \\
\text { Cultural Studies }\end{array}$ & $\begin{array}{l}\text { The methods in this chapter are primarily } \\
\text { used to generate the following types of } \\
\text { knowledge: } \\
\text { - Descriptive } \\
\text { - Exploratory } \\
\text { - Explanatory }\end{array}$ \\
\hline RESEARCH APPROACH & PURPOSE OF METHOD \\
\hline $\begin{array}{l}\text { The methods in this chapter originate } \\
\text { from or most commonly adopt the } \\
\text { following research approaches: } \\
\text { - Interpretive/subjective }\end{array}$ & $\begin{array}{l}\text { The most common purposes of using the } \\
\text { methods in this chapter are: } \\
\text { - System understanding } \\
\text { - Policy/decision support }\end{array}$ \\
\hline TEMPORAL DIMENSION & SYSTEMIC FEATURES AND PROCESSES \\
\hline $\begin{array}{l}\text { The methods in this chapter are most } \\
\text { commonly applied to the following } \\
\text { temporal dimensions: } \\
\text { - Present (typically within the last } \\
5-10 \text { years) } \\
\text { - Recent past (post-1700s) } \\
\text { - Future }\end{array}$ & \multirow[t]{3}{*}{$\begin{array}{l}\text { While most methods can do many } \\
\text { things, the methods in this chapter are } \\
\text { particularly good (i.e. go-to methods) for } \\
\text { addressing the following: } \\
\text { - SES components and linkages } \\
\text { - Power relations } \\
\text { - Transformation } \\
\text { - Evaluating policy options }\end{array}$} \\
\hline SPATIAL DIMENSION & \\
\hline $\begin{array}{l}\text { The methods in this chapter are primarily } \\
\text { either or both: } \\
\text { - Non-spatial } \\
\text { The methods in this chapter are most } \\
\text { commonly applied at the following } \\
\text { spatial scales: } \\
\text { - Local } \\
\text { - Regional (provincial/state } \\
\text { to continental) } \\
\text { - Global } \\
\text { - Multiple places/sites around the world }\end{array}$ & \\
\hline
\end{tabular}


various analytical methods to break away from theories and methods that assume that language is an autonomous system in which the meaning of words and sentences can always be constructed in an objective and internally fixed manner. In a sense, language is treated as being significantly more than just the medium through which we conduct research or communicate with one another.

Language and texts are seen as phenomena that have agency. Linked to this interpretation of the representational power of language, the notion of 'discourse' is then understood to be an 'interrelated set of texts, and the practices of their production, dissemination, and reception, that brings an object into being' (Parker 1992). The stories and narratives that are linked to organisations, traditions, practices and communities have the power to shape how these social forms are structured. From this view we can derive that qualitative methods aim to demonstrate how language and discourse produce social realities that shape certain practices and social-ecological interactions. As researchers, the use of qualitative methods of content analysis thus allows us to explore the relationship between constructed discourses and epistemic realities.

Qualitative methods for analysing linguistic content are used broadly to analyse textual and narrative-based content such as documents, interviews, observation notes and stories. There is a variety of qualitative analysis methods - some focusing on the explicit themes presented in the text, and others trying to disentangle the implicit or hidden patterns of meaning that are present in the text. Many researchers who use thematic analysis, for example, assume that the explicit content can be coded and analysed to unveil its inherent meaning. By contrast, an inherent and subtler or hidden pattern of meaning might be shaping certain perceptions, norms and societal orientations that only become explicit when highlighted through more reflective methods of textual and semiotic analysis like critical narrative inquiry. Some interpretive approaches to qualitative content analysis also take into consideration that meaning emerges as a result of researchers' relationship with the textual content in which their subjectivity comes to interact with the text.

The general purpose of qualitative content analysis methods is to make the various forms of 'meaning' that emerge through different methods of analysis, more explicitly noticeable. In some disciplines, this generative quality of meaning is called 'intertextuality', which highlights the fact that meaning also emerges through the way in which language and discourses are embedded in certain historical and social contexts and that meaning might change when the contexts change. These temporally linked changes can then also be tracked by methods such as narrative analysis or critical discourse analysis.

Interpretive and qualitative methods of content analysis explore and consider the different possible meanings people might attach to situated events or phenomena, or their connection to a certain place and the values that certain practices or objects hold for them. These methods aim to discover and explore the dominant discourses and how they are sustained or include and exclude people and practices in social-ecological systems (SES) relations. These methods are well suited to studying notions of identity construction, sense of place, sense-making, power relations and historical memory. They can also be used to discern what value judgements people might have towards certain events or objects.

Qualitative modes of research have a strong contemporary association with the humanities and social sciences, and different disciplines have developed diverse approaches for analysing textual or narrative-based phenomena. Practices and philosophies of interpretive content analysis also vary between academic disciplines. They all engage in a systematic reading or observation of fragmented texts or artefacts, which are then clustered or assigned labels or codes to extrapolate or infer meaning from them. The labels used in this analysis are not necessarily used consistently across disciplines. 
Qualitative methods of content analysis allow researchers to expose the diversity of perspectives different actors or groups might hold in relation to a specific problem, the nuances in meaning attributed to phenomena, and the dominant views that are present in a given context. They also provide insights as to why some views might be more dominant than others. As such, interpretive and qualitative methods of content analysis are likely to draw attention to the multiplicity of meanings and interpretations, and their consequences for how governance and stewardship interventions are implemented and enacted. These methods can also be used to understand how individuals position their own and others' personal and social identities in relation to some shared values or common resource-use problem, for example. In addition, the methods can highlight which forms of knowledge are considered valid by whom and what the consequences of certain positions are regarding access to resources and governance arrangements.

\section{SES problems and questions}

In seeking to understand social-ecological linkages, qualitative data can help researchers to address questions related to human-nature interactions (e.g. values, stewardship, resource use). To understand SES, research is needed on the institutional, social-relational, contextual and individual human dimensions of the system. Within each of these dimensions, a variety of themes and concepts can be explored and understood through qualitative data analysis methods. These methods are also useful for exploring the diverse understandings of SES held by various stakeholders and how the blind spots in their different ways of meaning creation shape people's experiences of using, governing and valuing certain resources, for example.

Typical questions that qualitative content analysis methods can help frame to address SES challenges include the following:

- What diverse understandings or interpretations of a problem exist in a given context?

- How do people group themselves in relation to the different understandings?

- What are the dominant views of a problem or challenge? How did these views become dominant?

- Whose interests are given advantage under the current management system? What are the underlying causes for that?

- Why do people have a specific relationship with their environment?

- What meanings do they attribute to that relationship?

- How do different meanings and interpretations affect the way SES are governed?

- How are meanings created and put into practice?

- Have perceptions of a place or definitions of a problem changed over time? How? Why?

Typical problems these methods seek to understand include:

- Why do conflicts of interest exist in the management of resources?

- How do different groups regard different approaches to environmental management as being successful (or not)?

- What are the power dynamics that govern the use of certain resources?

\section{Brief description of key methods}

In general, qualitative methods that focus on analysing narratives aim to understand how people make sense of, and reconstruct, their experiences from a particular standpoint in 
Rika Preiser et al.

Table 19.1 Summary of key methods used in qualitative content analysis

\begin{tabular}{|c|c|c|}
\hline Method & Description & References \\
\hline $\begin{array}{l}\text { Discourse } \\
\text { analysis }\end{array}$ & $\begin{array}{l}\text { Discourse analysis originated in linguistics, where it is } \\
\text { commonly defined as the analysis of a unit of language } \\
\text { (utterance or written text) larger than the sentence. Language } \\
\text { at this level cannot usefully be analysed with methods } \\
\text { traditionally associated with the decomposition of sentences or } \\
\text { verbal utterances/words. } \\
\text { Discourse analysis migrated into other social science domains, } \\
\text { where it has tended to be associated with the material culture } \\
\text { or 'texts' (e.g. novels, various forms of print/digital media } \\
\text { and formal publications more generally) rather than more or } \\
\text { less 'naturally' occurring (and transcribed) speech. Discourse } \\
\text { analysis is traditionally distinguished from the qualitative } \\
\text { analysis of interview transcripts or conversation transcripts } \\
\text { (using conversation analysis, which originated in sociology). } \\
\text { However, the post-1960 digitalisation of culture has blurred } \\
\text { this distinction. }\end{array}$ & $\begin{array}{l}\text { Key introductory texts } \\
\text { Jupp and Norris 1993; } \\
\text { Potter } 1996 \\
\text { Applications to SES } \\
\text { Dryzek 1997; } \\
\text { Feindt and Oels 2005; } \\
\text { Hajer and Versteeg } \\
2005\end{array}$ \\
\hline $\begin{array}{l}\text { Critical } \\
\text { discourse } \\
\text { analysis }\end{array}$ & $\begin{array}{l}\text { Critical discourse analysis (CDA) takes account of factors } \\
\text { beyond the text itself and emphasises the role of language as a } \\
\text { powerful resource that is related to ideology and socio-cultural } \\
\text { change. As a context-sensitive approach, CDA tends to uncover } \\
\text { the representational properties of language as a vehicle for } \\
\text { the exercise of power associated with the production and } \\
\text { circulation of texts. CDA is often combined with ethnography } \\
\text { to explore situated practices in a manner that can also } \\
\text { differentiate it from interviews and focus groups. }\end{array}$ & $\begin{array}{l}\text { Key introductory texts } \\
\text { Foucault 1974; } \\
\text { Weiss and Wodak 2003; } \\
\text { Blommaert 2005; } \\
\text { Hajer, Van den Brink, } \\
\text { and Metz } 2006 \\
\text { Applications to SES } \\
\text { Huitema } 2002\end{array}$ \\
\hline $\begin{array}{l}\text { Thematic } \\
\text { analysis } \\
\text { (text) }\end{array}$ & $\begin{array}{l}\text { The process of thematic analysis aims to identify themes - } \\
\text { also called patterns - in the dataset. These themes can be } \\
\text { explicitly stated in the data or can be implicitly present and } \\
\text { identified by the researcher. Thematic analysis can be developed } \\
\text { deductively, when themes are developed after theory or a } \\
\text { research question, or inductively, when the researcher searches } \\
\text { for themes in the data. Researchers can choose themes based on } \\
\text { their ability to provide an answer to the research question and } \\
\text { adequately synthesise the studied phenomenon. How frequently } \\
\text { a theme occurs does not necessarily determine its importance, } \\
\text { but rather indicates what constitutes specific patterns. There } \\
\text { are fundamentally three stages in the identification of themes: } \\
\text { (a) the researcher begins with an initial and holistic reading of a } \\
\text { text (e.g. an interview), (b) the researcher analyses or fragments } \\
\text { the text by identifying meaningful subsections ('meaning' is } \\
\text { defined in terms of prior reading, research questions, etc.) and } \\
\text { by coding or categorising the subsections, and (c) the researcher } \\
\text { elaborates and refines the emerging code system as more texts } \\
\text { (e.g. additional interviews) are put through this process. }\end{array}$ & $\begin{array}{l}\text { Key introductory texts } \\
\text { Jupp and Norris 1993; } \\
\text { Boyatzis 1998; } \\
\text { Braun and Clarke } 2006 \\
\text { Applications to SES } \\
\text { Stojanovic et al. 2016; } \\
\text { Sitas et al. } 2019\end{array}$ \\
\hline
\end{tabular}




\begin{tabular}{|c|c|c|}
\hline Method & Description & References \\
\hline $\begin{array}{l}\text { Narrative } \\
\text { analysis }\end{array}$ & $\begin{array}{l}\text { Narrative analysis provides researchers with a set of qualitative } \\
\text { approaches whereby stories and the events that shape the } \\
\text { temporal unfolding of events can be interpreted. These } \\
\text { stories can be collected through participatory data collection } \\
\text { methods (see Chapter 8) or shared through the everyday } \\
\text { lived experiences of people. The researcher interprets the } \\
\text { stories in terms of how the story is structured, what functions } \\
\text { the story has in the context of the storyteller, what the core } \\
\text { themes of the story are, and how the story is performed or } \\
\text { communicated. Narrative analysis is effective in exploring how } \\
\text { individuals confer meaning onto objects. It provides a means of } \\
\text { sense-making and meaning creation of experiences within the } \\
\text { individual's social environment. }\end{array}$ & $\begin{array}{l}\text { Key introductory texts } \\
\text { Bruner 1987; } \\
\text { Cortazzi 1993; } \\
\text { Boje } 2008 \\
\text { Applications to SES } \\
\text { Paschen and Ison } 2014\end{array}$ \\
\hline $\begin{array}{l}\text { Critical } \\
\text { narrative } \\
\text { inquiry }\end{array}$ & $\begin{array}{l}\text { As a form of 'sceptical reading', critical narrative inquiry (CNI) } \\
\text { exposes established and dominant narratives on the one hand } \\
\text { and informal narrative speculations and ante-narratives on the } \\
\text { other. By making this distinction apparent, the researcher can } \\
\text { look for the fragmented, non-linear, incoherent, collective, } \\
\text { unplotted stories in a specific context that do not or do not } \\
\text { yet form part of the main or dominant narratives, but bear the } \\
\text { potential to change these. } \\
\text { CNI reveals the unquestioned and taken-for-granted assumptions, } \\
\text { their internal tensions, contradictory forces and paradoxes lurking } \\
\text { behind the words in the text that have the power to shape } \\
\text { dominant narratives and support the power structures that are } \\
\text { propagated in this way. By exposing the nature and construction } \\
\text { of these narratives, people can reframe their worldviews and } \\
\text { sense-making and meaning-creation practices and are prompted } \\
\text { to consider alternative options for sense-making and acting in } \\
\text { their specific context. }\end{array}$ & $\begin{array}{l}\text { Key introductory texts } \\
\text { Boje 2011; } \\
\text { Edson and Klein } 2016 \\
\text { Applications to SES } \\
\text { Jørgensen and } \\
\text { Largacha-Martinez } \\
\text { 2014; } \\
\text { Klein and Weiland } 2014\end{array}$ \\
\hline $\begin{array}{l}\text { Interpre- } \\
\text { tative } \\
\text { phenom- } \\
\text { enological } \\
\text { analysis }\end{array}$ & $\begin{array}{l}\text { Having developed from the field of experiential and psychological } \\
\text { research, interpretative phenomenological analysis aims to } \\
\text { explore and interpret the particularities of people's lived } \\
\text { experiences (treated as 'text') in a given context and make sense } \\
\text { of a given phenomenon. Rooted in the theoretical origins of } \\
\text { phenomenology and hermeneutics, the methodology employs } \\
\text { a 'double hermeneutic' in which the researcher uses qualitative } \\
\text { data gathered through interviews, diaries or focus groups. } \\
\text { Engaging in flexible and open-ended inquiry, the researcher } \\
\text { adopts an exploratory mode of facilitation while trying to make } \\
\text { sense of the participants' stories as they make sense of how they } \\
\text { assign meaning to their lived experiences in relation to certain } \\
\text { phenomena. After data collection, the researcher analyses the } \\
\text { data for recurring themes that form patterns of meaning (ideas, } \\
\text { thoughts, feelings) throughout the text. The themes are used to } \\
\text { identify what issues matter to the participants (i.e. an object of } \\
\text { concern, topic of some import) and also how participants ascribe } \\
\text { meaning to certain phenomena and events. }\end{array}$ & $\begin{array}{l}\text { Key introductory texts } \\
\text { Reid, Flowers, and } \\
\text { Larkin 2005; } \\
\text { Smith, Flowers, and } \\
\text { Larkin 2009; } \\
\text { Gill 2014; } \\
\text { Kurtz 2014 } \\
\text { Applications to SES } \\
\text { Lejano, Ingram, and } \\
\text { Ingram 2013; } \\
\text { Lindow 2017 }\end{array}$ \\
\hline
\end{tabular}




\section{Case study 19.1: The technical discourse in water governance: who shapes SES in Peru and Brazil?}

Participatory stakeholder processes and collaborative governance have been recommended as key means for ensuring the sustainable management of common-use resources. The underlying hypothesis is that if actors with different interests come together, they will need to agree on the management of the resource, and thus come up with initiatives that allow them to sustain their own uses and conserve the resource. Yet, whether collaborative governance effectively manages to ensure more sustainable governance is strongly debated. In particular, the literature questions whether participatory forms of governance effectively manage to incorporate interests (e.g. the environmental protection/conservation interest) and perspectives (e.g. those of indigenous peoples) that have been historically excluded from management. While actors representing historically excluded interests might be physically present in participatory forums for environmental governance, the question that remains to be answered is whether they can actively participate in the discussions that lead to making decisions over the use of the resource.

In this case study, researchers analysed the discourses at play in four water-basin councils in Latin America, two in Peru and two in Brazil (Figure 19.1). The purpose of this study was to understand whether water-basin councils (i.e. participatory organisations set up to ensure the collegiate management of rivers) effectively include

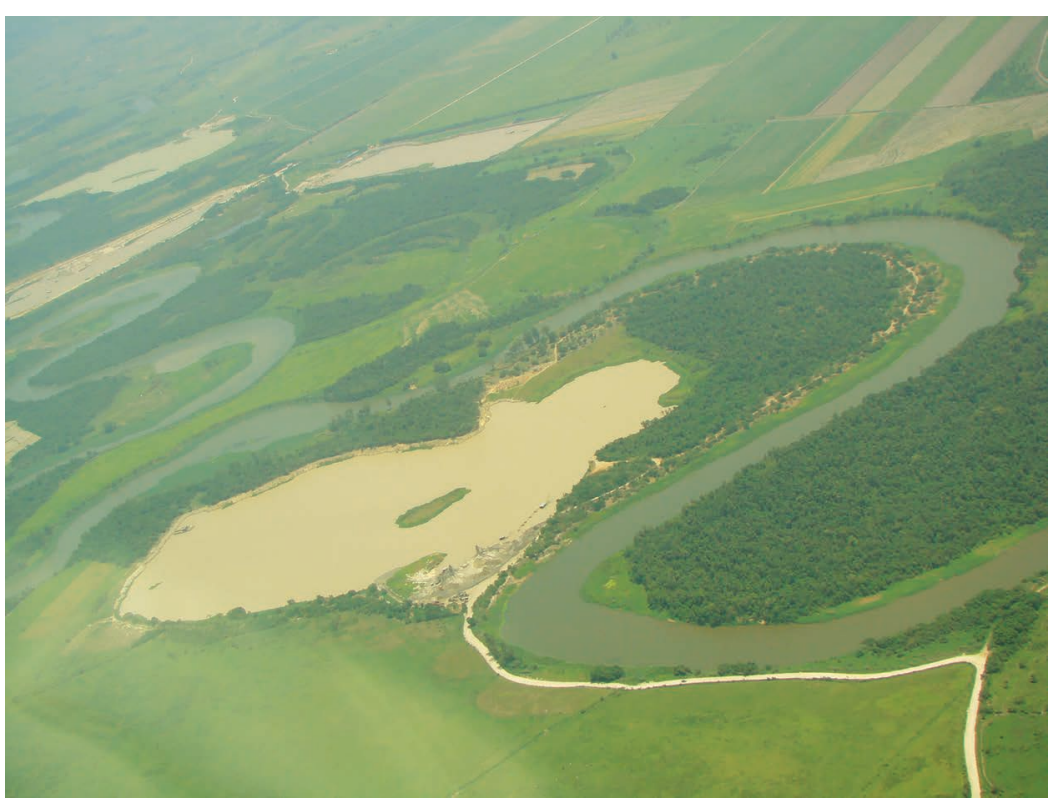

Figure 19.1 The degradation of the Paraíba do Sul River in Caçapava, southeastern Brazil (pt.wikipedia.org/wiki/Rio_Para\%C3\%ADba_do_ Sul\#/media/Ficheiro:Rio_para\%C3\%ADba_do_sul.jpg) 
actors who had historically been excluded from water governance (e.g. small NGOs, peasant communities) and what the conditions are that help or hinder their inclusion.

For data collection, the researchers used interviews, surveys and observation notes (Mancilla García and Bodin 2019). A thematic analysis was then applied to the data, i.e. the researchers identified the themes most frequently occurring in the interviews and observation notes. A deductive and an inductive approach were combined to determine these themes. This means they drew a first list of themes from the literature on participatory governance and inclusion. As they analysed the data to account for the themes or subthemes (specifications of more general themes) that appeared in the empirical material, the themes were revised.

The researchers complemented thematic analysis with critical discourse analysis to analyse which discourses or perspectives were considered valuable and appropriate by different participants in the council discussions. They examined what was considered valid and what not, and which types of actors were perceived as representative of valid, legitimate discourses. They also investigated what could not be said or was considered inappropriate and by whom. Besides identifying topics and linking those to discourses, the researchers explored which stakeholders perceived which discourses as either positive or negative.

The method allowed the researchers to identify the different themes present in the data and the perspective from which the themes had been presented. The theme 'environmental protection' was identified, for example, and linked to diverse discourses such as 'indigenous understanding', 'traditional management' or 'technical management'. This type of analysis allowed an organisation of the data that then helped to identify which discourses were considered valid and by whom. It provided insights into what power positions are associated with which discourses, and how power dynamics are embedded in discursive framings.

Since the purpose of the study was to assess each forum's capacity for inclusion of different actors, critical discourse analysis was found to be a most appropriate method. Indeed, the literature focusing on issues related to power distribution frequently has recourse to critical discourse analysis. The method is, however, very time consuming, since the data need to be read and classified multiple times - first to complete the list of themes, then to identify diverse perspectives on themes and finally to assess and organise the values attributed to the different discourses. While this fine analysis makes the method challenging to use, it provides nuanced data that allow one to understand the context specificities that explain why certain discourses are closer to power than others.

The method helped to expose the different discourses at play in the same forum, i.e. the different voices present and the relations between those voices in terms of power. Indeed, some discourses occupied more 'talking space' than others and were more likely to be guiding action than others. Certain voices were excluded: some of the participants said the forums did not provide them with the opportunity to express their vision of the environment in their own terms, which the researchers could observe through this method. In general terms - and despite the differences between the four forums studied - it can be said that technical and scientific language dominated in the forums. In some of the forums where indigenous peoples participated, they felt 
the forum was not a space in which their vision of management could be expressed. However, some of the previously excluded actors appropriated dominant discourses (technical, scientific) and used these to their advantage. Some of the environmentalists participating in the forums, for example, used technical knowledge to defend their position on the maximum volume of water that could be extracted from a river, and their concerns - expressed in technical terms - were taken into consideration by the rest of the participants.

Through discourse analysis, the researchers showed that discourses are actively transformed and performed as they are used to put forward different interests. However, interests that cannot be expressed in terms of scientific, technical or expert discourses, such as indigenous understandings, were difficult to integrate into the forums. The adoption of a critical perspective on discourse analysis made it possible to distinguish how discourses played out differently in each of the cases studied and how these discourses carried the weight of history in each of the countries studied. The researchers observed the dominance of technical discourses on irrigation in Peru

time. Through narratives, people make sense of events and experiences in order to orientate themselves and respond to events in the world. Through narrative we create coherence and unity from many different forces present in the context in which we live and act. Qualitative content analysis methods in an SES context focus on how meaning is attributed to certain situations and experiences and how that has material consequences in terms of access to and the governance of resources.

The different methods listed in Table 19.1 seek to explore how meaning emerges from texts and narratives and what can be inferred from these emergent patterns of meaning. As mentioned in the 'Introduction', the notion of 'meaning' varies from one approach to the next, depending on whether the method assumes that meaning is explicit and objectively present in the data (e.g. in the form of responses to interview questions) or whether meaning needs to be interpreted. Meaning can also be embedded in discursive practices that distribute power and define dominant or more marginal positions, i.e. the identity and social positioning of different actors are tightly linked to what they consider as the appropriate meaning of a resource or phenomenon.

\section{Limitations}

Interpretive and qualitative methods of content analysis are mostly open-ended inquiries where participants have more control over the content of the data collected. The nature of the research output changes, as do the challenges associated with generating these outputs. In a sense the researcher deals with 'warm data', i.e. the subjective perceptions of participants and researchers, relational interdependencies between different actors and human-nature interdependencies, and the contextual experiences of the participants. This makes the researcher's task of analysing the content challenging as it is difficult to verify the results objectively against the scenarios stated by the respondents. As a result, the reliability and validity of the research will not be verified in terms of its reproducibility, but in terms of whether or not the findings generated by the researcher provide deeper insights to synergise general themes. 
where the forums existed for a short period and still struggled to establish themselves as a permanent institution. In Brazil, where the forums had existed for longer, they seemed better able to accommodate different perspectives.

Critical discourse analysis was particularly useful to investigate the power dynamics and the distribution of roles in natural resource management. It situated issues of access to resources and their management in a historical perspective as the dominant discourses could be identified through time. It therefore made it possible to pinpoint changes in terms of who used dominant discourses and which discourses became valid. In addition, using critical discourse analysis in association with thematic analysis allowed the researchers to identify which topics are considered interesting within a given discourse.

The main challenge remained the time to analyse large amounts of data collected through interviews and observation notes. Only with the support of software was it possible to identify the co-occurrence and patterns of association of themes related to sentiments, and of discourses related to topics and actors.

Through this process, the researcher can uncover counter-discourses that inform mainstream conceptions of the phenomena under investigation. The transparency of the methods used allows the researcher to go beyond data collection and to analyse content by questioning how themes were identified, how discourses are distinguished from one another and how the researcher's position influenced particular results.

No perfect measure can be developed to remove the subjectivity of human experience. The researcher should therefore adopt a critical and reflexive attitude to identify and deal with the intersubjective biases and blind spots that inevitably arise when interpreting the modes and methods participants use to make sense of and create meaning from their lived experiences. The ethics of interpreting another person's lived experience can sometimes be challenging and could confront the researcher with uncomfortable situations. Allowing participants to read through the data and analyses and provide feedback on a researcher's interpretation of their responses will allow researchers to check for inconsistencies and reflect on their own assumptions. It will also indicate whether researchers should re-analyse their findings.

Key qualities required of a researcher are open-mindedness, patience, empathy, insight into human nature, emotional maturity and the willingness to enter into, and respond to, the participant's world.

\section{Resource implications}

Contrary to quantitative methods of data analysis, such as methods using objective coding or data-mining tools, interpretive and qualitative methods of content analysis do not rely on well-established software programs to run data analyses. Deriving the meaning of texts and narratives calls for good judgement, and careful reading with and against the dominant use of language and structural forms of meaning creation.

It is also likely that researchers will collect a much broader range of data than they can actually use in any specific research article. Because interactions need to be examined in 
fine-grained detail, the analysis will probably involve 'deep dives' into the data to identify critical incidents or interactions that are particularly revealing of the processes examined.

Researchers need to plan for having enough time to go through the data and find patterns of meaning. The process of analysing which words are associated with which, which sentiment is associated with certain words or ideas, and uncovering who defends which positions and why, could be very time consuming.

Good data collection is essential for sound data analysis. Training in computer-assisted qualitative analysis software (CAQDAS) such as NVivo, Atlas.ti, MaxQDA or Python might be essential. CAQDAS is often used to help manage and code very large amounts of data in well-organised ways as a first step in the process of doing narrative or discourse analyses. These software packages also provide automatic tools to search for or count words, and to see patterns in coding (e.g. which pieces of text were coded under several codes). This helps the researcher to identify associations that can support or reject different interpretations. Learning how to use these software programs requires a time investment and running them requires a financial one.

\section{New directions}

Responding to the limitations of discourse analysis and critical discourse analysis, the method of discourse practice analysis is on the rise. It acknowledges the difficulty of appropriating truth claims in qualitative interviews and focus groups by drawing on the assumption that people believe their own lies and build their sense-making and meaning-creation practices on paradigmatic references by hearsay. This assumption is based on the work of French literature scholar and author Pierre Bayard (2010). He related this phenomenon to the manner in which people create 'idiosyncratic' discourses about events and experiences they did not have in the same manner that they speak about books they have never read. The analysis of qualitative data in discourse practice analysis explores foci of attention, semantics and important distinctions to understand how the relevant stories are built and how they feed into the narratives in use. The discourse practice analysis reveals the so-called realms of possibilities for social systems which facilitate their ability to change.

\section{Key readings}

Bryman, A. 2016. 'Language in Qualitative Research.' In Social Research Methods (5th ed), 525-544. Oxford: Oxford University Press.

Dryzek, J. 1997. The Politics of the Earth: Environmental Discourses. Oxford: Oxford University Press.

Fairclough, N. 2003. Analysing Discourse: Textual Analysis for Social Research. London: Routledge.

Hajer, M.A., M. van den Brink, M., and T. Metz. 2006. 'Doing Discourse Analysis: Coalitions, Practices, Meaning.' In Words Matter on Policy and Planning: Discourse Theory and Method in the Social Sciences, edited by M. Brink and T. Metze, 65-74. Utrecht: Koninklijk Nederlands Aardrijkskundig Genootschap. http://hdl.handle.net/11245/1.289572.

Weiss G., and R. Wodak. 2003. 'Introduction: Theory, Interdisciplinarity and Critical Discourse Analysis.' In Critical Discourse Analysis, edited by G. Weiss and R. Wodak, 1-32. London: Palgrave Macmillan. doi:10.1057/9780230514560_1.

\section{References}

Bayard, P. 2010. How to Talk about Books You Haven't Read. New York: Bloomsbury.

Blommaert, J. 2005. Discourse - A Critical Introduction. Cambridge: Cambridge University Press.

Boje, D.M. 2008. Storytelling Organizations. Thousand Oaks: Sage.

Boje, D.M. 2011. 'Introduction to Agential Antenarratives that Shape the Future of Organizations.' In Storytelling and the Future of Organizations: An Antenarrative Handbook, edited by D.M. Boje, 1-19. New York: Routledge. 
Boyatzis, R. 1998. Transforming Qualitative Information: Thematic Analysis and Code Development. Thousand Oaks: Sage.

Braun, V., and V. Clarke. 2006. 'Using Thematic Analysis in Psychology.' Qualitative Research in Psychology 3(2): 77-101.

Bruner, J. 1987. 'Life as Narrative.' Social Research 54: 12-32.

Cortazzi, M. 1993. Narrative Analysis. London: Falmer Press.

De Saussure, F. 1974. Course in General Linguistics. London: Fontana.

Dryzek, J. 1997. The Politics of the Earth: Environmental Discourses. Oxford: Oxford University Press.

Edson, M.C., and L. Klein. 2016. 'Problem Structuring and Research Design in Systemic Inquiry.' In A Guide to Systems Research: Philosophy, Processes and Practice, Volume 10, edited by M.C. Edson, P. Buckle Henning, and S. Sankaran, 59-80. Dordrecht: Springer.

Feindt, P.H., and A. Oels. 2005. 'Does Discourse Matter? Discourse Analysis in Environmental Policy Making.' Journal of Environmental Policy E Planning 7(3): 161-173. 10.1080/15239080500339638.

Foucault, M. 1974. The Order of Things: An Archaeology of the Human Sciences. New York: Vintage.

Gill, M.J. 2014. 'The Possibilities of Phenomenology for Organizational Research.' Organizational Research Methods 17(2): 118-137.

Hajer, M.A., M. van den Brink, M., and T. Metz. 2006. 'Doing Discourse Analysis: Coalitions, Practices, Meaning.' In Words Matter on Policy and Planning: Discourse Theory and Method in the Social Sciences, edited by M. Brink and T. Metze, 65-74. Utrecht: Koninklijk Nederlands Aardrijkskundig Genootschap. http://hdl.handle.net/11245/1.289572.

Hajer, M., and W. Versteeg. 2005. 'A Decade of Discourse Analysis of Environmental Politics: Achievements, Challenges, Perspectives.' Journal of Environmental Policy \& Planning 7(3): 175-184.

Huitema, D. 2002. Hazardous Decisions: Hazardous Waste Siting in The UK, the Netherlands, and Canada. Dordrecht: Kluwer Academic Publishers.

Jørgensen, K., and C. Largacha-Martinez. 2014. Critical Narrative Inquiry: Ethics, Sustainability and Action to Critical Narrative Inquiry Storytelling, Sustainability and Power. New York: Nova Science Publishers.

Jupp, V., and C. Norris. 1993. 'Traditions in Documentary Analysis.' In Social Research - Philosophy, Politics and Practice, edited by M. Hammersley, 37-51. London: Sage.

Klein, L., and C.A.P. Weiland. 2014. 'Critical Systemic Inquiry: Ethics, Sustainability and Action.' In Critical Narrative Inquiry: Storytelling, Sustainability and Power, edited by K.M. Jørgensen and C. Largacha-Martinez, 145-158. New York: Nova Science Publishers.

Kurtz, C. 2014. Working with Stories (3rd ed). Creative Commons, Kindle edition.

Lejano, R., M. Ingram, and H. Ingram. 2013. The Power of Narrative in Environmental Networks. Cambridge: MIT Press.

Lindow, M. 2017. 'Exploring Resilience Capacities through the Art of Storymaking: The Case of Food Innovators in the Western Cape.' MPhil diss., Stellenbosch University. http://hdl.handle. net/10019.1/102910.

Mancilla García, M., and Ö. Bodin. 2019. 'Participatory Water Basin Councils in Peru and Brazil: Expert Discourses as Means and Barriers to Inclusion.' Global Environmental Change 55: 139-148. doi:10.1016/j.gloenvcha.2019.02.005.

Parker, I. 1992. Discourse Dynamics. London: Routledge.

Paschen, J-A., and R. Ison. 2014. 'Narrative Research in Climate Change Adaptation-Exploring a Complementary Paradigm for Research and Governance.' Research Policy 43(6): 1083-1092.

Potter, J. 1996. Representing Reality: Discourse, Rhetoric and Social Construction. London: Sage.

Reid, K., P. Flowers, and M. Larkin. 2005. 'Exploring Lived Experience: An Introduction to Interpretative Phenomenological Analysis.' The Psychologist 18(1): 20-23.

Sitas, N., Z.V. Harmáčková, J.A. Anticamara, A. Arneth, R. Badola, R. Biggs, R. Blanchard et al. 2019. 'Exploring the Usefulness of Scenario Archetypes in Science-Policy Processes: Experience Across IPBES Assessments.' Ecology and Society 24(3): 35. doi:10.5751/ES-11039-240335.

Smith, J.A., P. Flowers, and M. Larkin. 2009. Interpretative Phenomenological Analysis. Thousand Oaks: Sage.

Stojanovic, T., H. McNae, P. Tett, T.W. Potts, J. Reis, H.D. Smith, and I. Dillingham. 2016. 'The "Social" Aspect of Social-Ecological Systems: A Critique of Analytical Frameworks and Findings from a Multisite Study of Coastal Sustainability.' Ecology and Society 21(3): 15. doi:10.5751/ ES-08633-210315.

Weiss, G., and R. Wodak. 2003. 'Introduction: Theory, Interdisciplinarity and Critical Discourse Analysis.' In Critical Discourse Analysis, edited by G. Weiss and R. Wodak, 1-32. London: Palgrave Macmillan. doi:10.1057/9780230514560_1. 